\title{
HUBUNGAN STATUS GIZI DENGAN TUMBUH KEMBANG ANAK USIA PRA SEKOLAH DI TK ALBINA BANDA ACEH
}

\author{
Relationship Of Nutritional Status With Growth Of Children's Age Pre-School In \\ Tk Albina Banda Aceh \\ Ismiati $^{* 1}$, Suci Mentari Maulida ${ }^{2}$ \\ ${ }^{1,2}$ Fakultas Ilmu Kesehatan, Universitas Ubudiyah Indonesia, Banda Aceh \\ Email: ismi@uui.ac.id*1,maulida@yahoo.com²
}

\begin{abstract}
ABSTRAK
Di Provinsi Nanggroe Aceh darussalam pada tahun 2008 terdapat balita status gizi baik 10.115 (73,5\%), gizi kurang sebanyak 2.993 (21,7\%), gizi buruk sebanyak 467 (3,4\%) dan gizi lebih sebanyak $191(1,4 \%)$. Di Banda Aceh terdapat sebanyak 4.673 balita,terdapat balita status gizi baik $71,8 \%$, gizi kurang sebanyak $23,8 \%$, gizi buruk sebanyak 3,6 \% dan gizi lebih sebanyak 1 \%.Di TK Albina Banda Aceh terdapat balita gizi kurang sebanyak 7 orang. Penelitian ini bertujuan untuk mengetahui hubungan status gizi dengan tumbuh kembang anak meliputi perkembangan kognitif dan perkembangan bahasa. Metode penelitian ini bersifat Deskriptif Analitik dengan desain Cross Sectional Study yang di lakukan di TK Albina Banda Aceh dari tanggal 03 Januari - 20 Januari 2108 dengan jumlah sampel 60 orang. Analisis yang di gunakan adalah dengan analisis Univariat dan Bivariat. Uji statistik dengan menggunakan Chi-Square dengan program komputer SPSS versi 11.000 dengan tingkat kemaknaan 95\% dan derajat kebebasan. Dari hasil penelitian diperoleh status gizi anak dengan gizi baik 88,33\%, dan gizi kurang 11,67\% dengan perkembangan kognitif yang baik $85 \%$, sedang $15 \%$, dan perkembangan bahasa yang baik $78,33 \%$ dan sedang $21,67 \%$. Kesimpulan didapat ada hubungan antara status gizi dengan tumbuh kembang anak yang meliputi perkembangan kognitif dan bahasa.

Kesimpulan dan Saran : Diharapkan kepada instansi tenaga kesehatan agar dapat memberikan penyuluhan kepada masyarakat atau keluarga tentang pentingnya gizi terhadap tumbuh kembang anak terutama anak usia pra sekolah.
\end{abstract}

\section{Kata Kunci : Status gizi , Tumbuh Kembang Anak}

\begin{abstract}
In the Province of Nanggroe Aceh Darussalam in 2008 there were underfives with good nutritional status 10,115 (73.5\%), 2,993 (21.7\%) undernourished, 467 (3.4\%) malnutrition and 191 (1\%) overnutrition 4\%). In Banda Aceh there were 4,673 children under five, there were underfives with good nutritional status, $71.8 \%$, under nutrition as many as $23.8 \%$, poor nutrition as many as $3.6 \%$ and over $1 \%$ nutrition. 7 people. This study aims to determine the relationship of nutritional status with child development including cognitive development and language development. This research method is Descriptive Analytic with Cross Sectional Study design conducted at Albina Banda Aceh Kindergarten from January 3 to January 20, 2108 with a sample of 60 people. The analysis used is the analysis of Univariate and Bivariate. Statistical test using Chi-Square with SPSS version 11,000 computer program with a significance level of 95\% and degrees of freedom. From the results of the study it was obtained the nutritional status of children with good nutrition $88.33 \%$, and malnutrition $11.67 \%$ with good cognitive development $85 \%$, moderate $15 \%$, and good language development $78.33 \%$ and moderate $21.67 \%$. The conclusion is that there is a relationship between nutritional status and child development which includes cognitive and language development.
\end{abstract}


Conclusions and Recommendations: It is expected that health personnel agencies can provide counseling to the community or family about the importance of nutrition to the growth and development of children, especially pre-school age children.

\section{Keywords: Nutritional status, Child Growth}

\section{PENDAHULUAN}

Pada usia dini khususnya pada usia dibawah lima tahun (balita) banyak permasalahan yang dihadapi, diantaranya adalah masalah kekurangan energi protein. Kurang energi protein (KEP) adalah salah satu masalah gizi yang disebabkan oleh menurunnya status gizi pada anak balita (Depkes RI, 1993).

Status gizi adalah keadaan kesehatan individu atau kelompok yang ditentukan oleh derajatbkebutuhan fisik akan energi dan zat-zat yang diperoleh dari beragam makanan yang berdampak fisiknya di ukur secara antropometri (Soehardjo).

Menurut Santoso (1999) ada dua faktor yang mempengaruhi proses tumbuh kembang optimal seorang anak, yaitu faktor dalam dan faktor luar. Adapun yang termasuk dalam faktor dalam adalah keturunan, kemampuan intelektual berfikir dan sifat (Tempramen), sedangkan faktor dari luar adalah keluarga, gizi, budaya, teman bermain dan sekolah.

Pertumbuhan dan perkembangan merupakan proses yang terjadi pada setiap makhluk. Manusia, terutama pada masa kanak-kanak mengalami proses tumbuh kembang secara cepat. Pertumbuhan dan perkembangan setiap anak memiliki ciri khas yang tersendiri. Pertumbuhan yang terjadi pada seorang tidak hanya meliputi yang terlihat seperti pertumbuhan fisik, tetapi juga pertumbuhan dan perkembangan dalam segi seperti berfikir, berperasaan, bertingkah laku dan lainnya (Santoso, 1999).

Di Banda Aceh terdapat jumlah balita sebanyak 4.673 balita, terdapat balita status gizi baik sebanyak 71,8 \%, gizi kurang sebanyak 23,8 \%, gizi buruk sebanyak 3,6 \% dan gizi lebih sebanyak $1 \%$ (Dinkes Aceh, 2009).

Berdasarkan hasil Hasil Penelitian Di TK Albina Banda Aceh Tahun 2018 dengan jumlah murid 178 orang, Populasi yang saya ambil 120 dimana kelas I-A 40 orang, kelas I-B 40 orang, kelas II 40 orang. Sampel yang di teliti 60 orang maka terdapat balita bergizi kurang 7 orang, gizi baik 53 orang, gizi buruk 0 , gizi lebih 0.yang harus di teliti adakah hubungan status gizi dengan tumbuh kembang anak usia prasekolah. Perkembangan kognitif Di TK Albina Banda Aceh Tahun 2018, anak mulai dapat berjalan dengan menggunakan pikirannya dan mampu mengungkapkan pengalaman masa lalu tetapi ada juga yang belum bisa mengungkapkan masa 
lalu dan belum dapat menghitung dengan benar sedangkan perkembangan bahasa anak ada yang belum mampu menggunakan tata bahasa yang bagus seperti bertanya, bernyanyi dan lainnya.

Berdasarkan permasalahan di atas maka peneliti tertarik untuk melakukan penelitian dengan judul "Hubungan Status Gizi dengan Tumbuh Kembang Anak Usia Pra sekolah Di TK Albina Banda Aceh.

\section{METODE PENELITIAN}

Adapun jenis penelitian ini adalah desktiptif analitik, yaitu dengan menggunakan cross seectional studi. Dalam penelitian ini akan di gambarkan tentang status gizi dengan tumbuh kembang anak usia pra sekolah Di TK Albina Banda Aceh. Populasi dalam penelitian ini adalah anak usia Di TK Albina Banda Aceh Tahun 2018 dengan jumlah populasi 120 orang.

Untuk mengetahui status gizi anak usia prasekolah diukur dengan memperhatikan BB/U yang digolongkan menurut nilai baku standar WHO-NCHS yaitu:
a. Gizi lebih bila BB/U > 110\% b) Gizi baik bila BB/U 81-110\% c) Gizi kurang bila BB/U 60-80\% d) Gizi Buruk bila BB/U $\leq 60 \%$.
b. Untuk mengukur tumbuh kembang anak usia prasekolah pengkatagoriannya dilakukan dengan kriteria:
c. Baik, bila x $\geq 48$ Sedang, bila $36 \leq x<47$ Kurang, bila $x<24$

1. Untuk mengetahui pertumbuhan kognitif anak usia prasekolah pengkatagoriannya dilakukan dengan kriteria:
a. Baik, bila $x \geq 32$ Sedang bila $24 \leq x<32$
b. Kurang bila $\mathrm{x}<16$

2. Untuk mengetahui perkembangan bahasa anak usia prasekolah pengkatagoriannya dilakukan dengan kriteria:
a. Baik bila $x \geq 24$
b. Sedang bila $18 \leq x<24$ c). Kurang bila $x<18$ 


\section{HASIL DAN PEMBAHASAN}

1. Hubungan antara perkembangan bahasa dengan status gizi

Tabel 1

Distribusi Frekuensi Hubungan Antara Perkembangan Bahasa dengan Status Gizi Di TK Albina Banda Aceh

\begin{tabular}{|c|c|c|c|c|c|c|c|c|}
\hline \multirow{2}{*}{ Status Gizi } & \multicolumn{9}{|c|}{ Perkembangan Bahasa } & \multicolumn{2}{c|}{ Total } \\
\cline { 2 - 9 } & \multicolumn{2}{|c|}{ Baik } & \multicolumn{2}{|c|}{ Sedang } & Kurang & \multicolumn{2}{c|}{} \\
\cline { 2 - 9 } & F & \% & F & \% & F & \% & & 0 \\
\hline Gizi lebih & 0 & 0 & 0 & 0 & 0 & 0 & 0 & 0 \\
\hline Gizi baik & 45 & 84,9 & 8 & 15,1 & 0 & 0 & 53 & 100 \\
\hline Gizi kurang & 2 & 28,6 & 5 & 71,4 & 0 & 0 & 7 & 100 \\
\hline & 47 & & 13 & & 0 & & 60 & \\
\hline
\end{tabular}

Berdasarkan tabel di atas dapat disimpulkan bahwa dari 53 jumlah responden yang status gizinya baik memiliki perkembangan bahasa dalam keadaan baik 84,9\% (45 orang) dan perkembangan bahasa yang sedang $15,1 \%$ (8 orang) sementara dari 7 responden yang status gizinya kurang memiliki perkembangan bahasa dalam keadaan baik 28,6\% (2 orang) dan perkembangan bahasa yang sedang 71,4\% (5 orang). Serta tidak ada dari respoden yang memiliki status gizi lebih.

Bila diperhatikan dari hasil penelitian, kita dapat melihat pada responden nomor 10, 13, 24, 44 dan responden nomor 54 dimana mereka mempunyai perkembangan bahasa pada kategori sedang dan status gizinya dalam batasan gizi sedang juga. Berdasarkan hasil penelitian didapatkan juga bahwa sebagian besar dari responden mempunyai perkembangan bahasa yang sebagian besar dalam kategori baik.

2. Hubungan antara perkembangan kognitif dengan status gizi

Tabel 2

Distribusi Frekuensi Hubungan Antara Perkembangan Kognitif Dengan Status Gizi Di TK Albina Banda Aceh

\begin{tabular}{|c|c|c|c|c|c|c|c|c|}
\hline \multirow{2}{*}{ Status Gizi } & \multicolumn{6}{|c|}{ Perkembangan Kognitif } & \multicolumn{2}{|c|}{ Total } \\
\cline { 2 - 9 } & \multicolumn{2}{|c|}{ Baik } & \multicolumn{2}{c|}{ Sedang } & \multicolumn{2}{c|}{ Kurang } & \multicolumn{2}{c|}{} \\
\cline { 2 - 9 } & F & \% & F & \% & F & \% & & \\
\hline Gizi lebih & 0 & 0 & 0 & 0 & 0 & 0 & 0 & 0 \\
\hline Gizi baik & 49 & 92,5 & 4 & 7,5 & 0 & 0 & 53 & 100 \\
\hline Gizi kurang & 2 & 28,6 & 5 & 71,4 & 0 & 0 & 7 & 100 \\
\hline & 51 & & 9 & & 0 & & 60 & \\
\hline
\end{tabular}


Journal of Healthcare Technology and Medicine Vol. 4 No. 1 April 2018

Universitas Ubudiyah Indonesia

e-ISSN : 2615-109X

Berdasarkan hasil analisa dengan menggunakan metode statistik Chi-Square dengan bantuan SPSS versi 11.00 dengan tingkat kemaknaan ( $\square$ ) adalah 0,05 dan derajat kebebasan (df) = 1 didapatkan hasil ada hubungan antara perkembangan kognitif dengan status gizi anak usia prasekolah di Taman Kanak-Kanak Semai Benih Bangsa.

Hal ini sesuai dengan teori yang penulis dapatkan yaitu menurut Patmonodewo (2000) yang menyatakan bahwa pada tahap prasekolah, perkembangan kognitif anak sudah mulai dapat belajar dengan menggunakan pemikirannya, proses pikir anak berpusat pada penguasaan simbol-simbol (misalnya kata-kata), mampu mengungkapkan pengalaman masa lalu dan membanyangkan benda yang tidak nampak secara fisik. Selanjutnya Berg (1986) menyatakan anak yang memiliki gizi buruk memiliki otak yang lebih kecil dari ukuran rata-rata. Anak- anak yang pernah satu kali terkena gizi kurang maka kurang kemampuan dalam tes mental di kemudian hari.

Berdasarkan hasil penelitian dapat diperhatikan bahwa responden no. 10, 13, 24, 44, dan 54 mempunyai perkembangan kognitif yang sedang dan dapat diperhatikan mengalami status gizi yang sedang juga. Sementara dari hasil tabel distribusi frekuensi didapatkan bahwa sebagian besar anak di TK tersebut memiliki perkembangan kognitif yang baik pula.

3. Hubungan antara tumbuh kembang dengan status gizi

Tabel 3

Distribusi Frekuensi Hubungan Antara Tumbuh Kembang Dengan Status Gizi Di TK Albina Banda Aceh

\begin{tabular}{|c|c|c|c|c|c|c|c|c|}
\hline \multirow{3}{*}{ Status Gizi } & \multicolumn{6}{|c|}{ Tumbuh Kembang } & \multirow{2}{*}{\multicolumn{2}{|c|}{ Total }} \\
\hline & \multicolumn{2}{|c|}{ Baik } & \multicolumn{2}{|c|}{ Sedang } & \multicolumn{2}{|c|}{ Kurang } & & \\
\hline & $\mathbf{F}$ & $\%$ & $\mathbf{F}$ & $\%$ & $\mathbf{F}$ & $\%$ & & \\
\hline Gizi lebih & 0 & 0 & 0 & 0 & 0 & 0 & 0 & 0 \\
\hline Gizi baik & 49 & 92,5 & 4 & 7,5 & 0 & 0 & 53 & 100 \\
\hline Gizi kurang & 2 & 28,6 & 5 & 71,4 & 0 & 0 & 7 & 100 \\
\hline & 51 & & 9 & & 0 & & 60 & \\
\hline
\end{tabular}

Berdasarkan hasil analisa dengan menggunakan metode statistik Chi-Square dengan bantuan SPSS versi 11.00 dengan tingkat kemaknaan ( $\square$ ) adalah 0,50 dan derajat kebebasan (df) = 1 didapatkan hasil ada hubungan antara tumbuh kembang dengan status gizi anak usia prasekolah di Taman Kanak-Kanak Semai Benih Bangsa. 
Journal of Healthcare Technology and Medicine Vol. 4 No. 1 April 2018

Universitas Ubudiyah Indonesia

e-ISSN : 2615-109X

Hal ini sesuai dengan pendapat yang dikemukakan oleh Beck (1995) yang menyatakan bahwa status gizi merupakan refleksi kecukupan zat gizi yang merupakan salah satu parameter penting dalam menilai tumbuh kembang anak dan keadaan kesehatan pada umumnya.

Menurut Soetjiningsih (2001) tingkat perkembangan dan pertumbuhan seorang anak dipengaruhi status gizinya dimana status gizinya sangat dipengaruhi oleh beberapa hal, salah satunya adalah tingkat pengetahuan. Oleh karena itu, diharapkan kepada pihak sekolah untuk memberikan pengarahan orang tua anak dalam pemenuhan kebutuhan gizi anak, karena gizi sangat mempengaruhi kecerdasan atau pola pikir anak.

\section{KESIMPULAN}

1. Terdapat hubungan antara status gizi dengan tumbuh kembang anak usia prasekolah ditinjau dari segi perkembangan kognitif pada anak usia prasekolah Di TK Albina Banda Aceh

2. Terdapat hubungan antara status gizi dengan tumbuh kembang anak ditinjau dari perkembangan bahasa anak usia prasekolah Di TK Albina Banda Aceh

\section{DAFTAR PUSTAKA}

Depkes RI. 1993 Asuhan Kesehatan Anak Dalam Konteks Keluarga. Pusat Pendidikan Tenaga Kesehatan. Jakarta.

Depkes RI. 2003. Status Gizi Kelurga. Pusat Pendidikan Tenaga Kesehatan. Jakarta. Santoso. 1999. Kesehatan dan Gizi, PT. Rineka Cipta. Jakarta

Soetjiningsih. 1999. Tumbuh Kembang Anak, Penerbit EGC. Jakarta. 